\title{
ИоннНа Вох
}

Лодзинский университет, Филологический факультет, Институт русистики, Кафедра языкознания (Лодзь, Польша)

\section{Стилистика акцентных вариантов в современном русском языке}

Настоящая статья представляет собой описание и анализ акцентных вариантов современного русского языка с точки зрения их стилистической окраски. Сущность проблемы сводится к тому, что русское ударение в определенной речевой ситуации может существенным образом изменить стилистическую окраску слова и даже всего высказывания. Незнание правил постановки ударения или, наоборот, сознательное игнорирование в речи акцентологической нормы существенным образом могут повлиять на успешность достижения говорящим коммуникативной цели. Актуальность вопроса не вызывает сомнений в связи с ролью ударения в фиксировании стилистических отличий между акцентными вариантами в системе русского языка. Очевидным, однако, является положение о том, что ударение в русском языке выполняет и стилистическую функцию, так как неуместно использованный в речи ненормативный вариант ударения всегда стилистически окрашен, независимо от того, было ли использование данного варианта намеренным или нет. Иными словами, акцентологическая правильность высказывания или отсутствие знаний в области ударения провоцирует действие стилистики языка. В качестве иллюстрации используем примеры из СМИ и соответствующих научных публикаций.

Как отмечалось выше, использование неуместно подобранного к данной речевой ситуации акцентного варианта может быть преднамеренным (сознательным) или ошибочным (несознательным). Несознательное употребление неподходящего по отношению к стилю речи акцентного варианта связано, как правило, с незнанием литературной нормы в узком смысле этого слова, то есть кодифицированной формы русского литературного языка (Крысин 2007: 5-17). Отсутствие знаний в области русской орфоэпии особенно заметно в публичных высказываниях. Публичной речи все чаще присуще употребление неправильных форм, нарушение акцентологических норм, небрежность по отношению к языку. Это своего рода обратный, по отношению к строгой советской нормализации публичной речи процесс, кото- 
рый является доказательством вторжения просторечия в литературный язык. Несоблюдение акцентологической нормы является ярким свидетельством проникновения просторечия в речь людей образованных. Вследствие этого процесса литературный язык постепенно становится конгломератом элементов, свойственных необразованным пластам общества и кодифицированного языка, регулируемого консервативной нормой. В монографии Не говори шершавым языком (Горбаневский, Караулов, Шаклеин) собраны примеры нарушений литературной нормы, допущенные в течение 1996-1999 годов сотрудниками средств массовой информации, дикторами радио- и телевидения, политиками, деятелями культуры и др., например:

«Не покупайте крем для загара в Москве, лучшие крема вы купите здесь, на Кубе...»; «Лучшие крема - в магазине «Бурда-Авангард» (норма: кремы)

«Чтоб меня не обвинили матеря солдат...»

«Правительство может кондитерам дать оборотные средстваџ»

«Екатерина Фурцева посуровела и сказала...»

«Самолет вновь поднялся в воздух...»

«Говорят, у Брежнева был инсульт...»

«Наччалось это время коррупции и взяток...»

«Между тем международные организации пытаются хоть как-то облегчить участь

беженцев»

«Она [Фурцева] уже тогда начала увлекаться волейболом»

«Отснятая пленка была без звука»

«Сибирская областная филармония меня не приняла»

Приведенные выше примеры являются своеобразной смесью литературного языка и городского просторечия. Городское просторечие - языковой феномен, сложившийся в русском языке в крупных населенных пунктах, характеризующийся синкретизмом профессиональной речи, жаргонизмов, арго, диалектизмов и литературной речи с ее кодифицированной нормой. Городское просторечие имеет ряд особенностей, например стилистическую недифференцированность языковых явлений, бесписьменность, функциональную «монотонность» (Капанадзе 1984: 8). Можно выделить несколько характерных черт городского просторечия. Одной из них является неограниченное распространение ударяемой флексии -а в именительном падеже множественного числа существительных, например: слесаря, шофера, крема

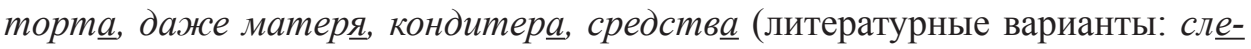
сари, шофёры, кремы, торты, матери, кондитеры, среддства) и под. Следующая черта - это смешение флексий во множественном числе вместе с акцентной характеристикой слова, то есть вместе с неправильной ударяемой флексией -а во множественном числе ударение остается на неправильной флексии, что обычно касается существительных, имеющих в родительном падеже нулевую флексию (Земская 1984: 74-75): местов, делов, зеркалов, тортов. Иными словами, слово, независимо от рода, в просторечии может 
получить новый фоно-морфологический вариант (Девкин 1984: 14) с ударением на флексии, причем литературной нормой такие варианты не допускаются, так как они относятся к профессиональной речи, ср. специальные нелитературные варианты в специальной речи: брамсель -я, мн. -и, -ей // в специальной речи мн. брамселя, брамселей; марсель -я, мн. -и, -ей // в спец. речи мн. марселя, марселей; надфиль-я, мн. -и, -ей // в спец. речи мн. надфиля, надфилей; боиман, мичман -a, мн. -bl, -ей // в речи моряков мн. мичмана, мичманов; каупер -а, мн. -bl, -ов // в проф. речи мн. каупера, кауперов.

Ударяемый префикс в формах прошедшего времени, например: приняла, наччала, наччалось, поднялся - это тоже примеры неправильных с точки зрения нормы, но широкоупотребительных вариантов, свидетельствующих о массовом, ускоренном по отношению к норме выравниванию ударения в области парадигмы, даже в форме женского рода, которая должна выделяться среди остальных форм ударением на флексии: начал, начало, начали, но на-

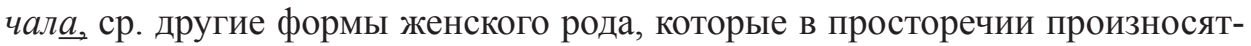
ся с ударением на основе: брала, взяла, ждала (Санджи-Гаряева 1984: 169).

В случае неоправданного и чрезмерного употребления образованными людьми в публичной речи вышеупомянутых, то есть грубо неправильных акцентных вариантов, не может не сложиться у адресатов высказывания впечатление о недостаточной образованности говорящего, о том, что адресант не осознает ошибочность. Кроме того, речь, построенная на литературном языке, не должна содержать элементов просторечия, так как просторечие ненормализованная речь, нарочито небрежная и «фривольная» (Орлов 1981: 125). С другой стороны, просторечные варианты ударения могут сознательно употребляться в речи, например, политиков с целью создания некоей фамильярности с электоратом, большинство которого пользуется просторечием. Следует отметить, что часто употребляемые, но просторечные акцентные варианты (грубо неправильные в литературном языке) часто осуждаются средствами массовой информации или Интернет-пользователями, которые высмеивают, часто в графической форме, отсутствие знаний акцентных правил среди общества.

Однако, в то же время, ударение может служить намеренным средством различения разных стилей речи. По словам Р. И. Аванесова, «Функциональные отношения между разными по месту ударения вариантами могут быть весьма различны ${ }^{1}$

1. Один из частных случаев акцентной вариантности образует функциональное тождество, безразличие, равноправие вариантов (ср., например:

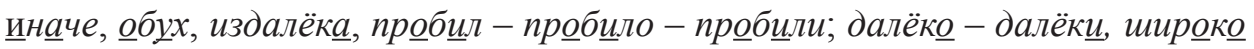
- широки);

Здесь и в дальнейшем цит. по: Аванесов Р. И., Акиентная вариантность и вокализм слова, [в:] Теория языка. Англистика. Кельтология, Москва, 1976, с. 5-10. 
2. Второе ударение может быть менее предпочтительным, допусти-

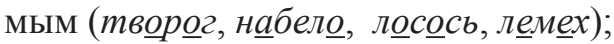

3. Разговорным (подал, заддал, отдал, отнял, поднял, лмоть, догговор, ханжество);

4. Просторечным (ㅁeㄹ, алкоголь);

5. Просто неправильным, хотя и широкоупотребительным (таможня,

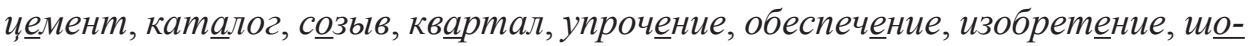
фер, километр, сантиметр, окон, звонишь);

6. Устарелым (диалог, библиотека, астроном);

7. Устарелым и поэтическим (начㅁтый - начатый современная нор-

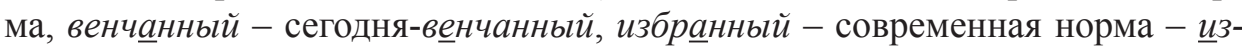
бранный);

8. Фольклорным (девица, молодец, богатырь, милой, мелковый).

Следует добавить, что данная классификация акцентной вариантности является сегодня в некоторых случаях устаревшей, так как литературная норма меняется и некоторые варианты, которые Р. И. Аванесовым считались неправильными, сегодня вошли в ранг нормы или стали равноправными литературному варианту, например: творог и творог, подал и подал, обеспечение и обеспечение и др. ${ }^{2}$ Не можем также согласиться с мнением, что акцентные варианты могут быть «просто неправильными, хотя и широкоупотребительными», так как каждый неправильный с точки зрения литературной нормы вариант, неуместно употребленный, стилистически окрашен. Благодаря непрерывному развитию акцентной системы, убыванию старых вариантов и появлению новых, как устаревшие, так и просторечные варианты ударения могут использоваться как одно из средств стилизации, например, в стихотворениях или фильмах, песнях, анекдотах. В российской мелодраме «Путь к сердцу мужчины» (год выпуска: 2013, режиссер: Михаил Жерневский) ударение тоже является одним из средств стилизации речи главной героини - Анюты, простой необразованной молодой девушки, прибывшей в Москву из захолустного городка, которая в речи допускает целый ряд ошибок, присущих необразованному человеку, в том числе и акцентологических, например: «Я сама с ружьём ходила, нашего медведя видела...», «как тёть одна справляется: тут зеркалов штук десять». Неслучайно в песне Потапа и Насти Каменских «На районе», в которой речь идет о повседневной жизни жителей района большого города, припев начинается со слов: «У нас на районе не звонят, а звонят, стены все в болоне, Вася, что ты гонишь» ${ }^{3}$. Неправильный вариант звонят, так как и большое количество просторечной и жаргонной лексики употребляются здесь с определенной целью: подчеркнуть характер языка большого города; ударение тоже отличает

По Орфоэпическому словарю русского языка авторства И. Л. Резниченко (Москва 2008). http://www.gl5.ru/potap_i_nastya_kameskyh_na_raione.html. 
речь литературную от «нарочно неправильной», которая все чаще одерживает победу над литературной речью.

В заключение следует сказать, что ударение является дополнительным средством, связывающим говорящего с определенной социальной группой, определяет уровень его образованности или происхождение, отношение к родному языку. Большое количество употребляемых в речи неправильных просторечных вариантов ударения может в будущем повлиять на ускоренное изменение нормы литературного языка, которая является крайне сложной, на первый взгляд и противоречивой. Постоянно меняющаяся, вместе с эволюцией языка, норма оказывается ненужной для обычного носителя русского языка.

\section{Bibliografia}

Аванесов Р. И. (1976), Акиентная вариантность и вокализм слова, [в:] «Теория языка. Англистика. Кельтология», Москва.

Горбаневский М. В., Караулов Ю. Н., Шаклеин В. М., Не говори шершавым языком (О нарушениях норм литературной речи в электронных и печатных СМИ), [в:] http:/gramota. ru/biblio/research/rubric_370/.

Девкин В. Д. (1984), О видах нелитературности речи, [в:] Городское просторечие. Проблемь изучения, Москва, с. 14.

Земская Е. А., Китайгородская М. В. (1984), Наблюдения над просторечной морфологией, [в:] Городское просторечие. Проблемы изучения, Москва, с. 74-75.

Капанадзе Л. А. (1984), Современное городское просторечие и литературный язык, [в:] Городское просторечие. Проблемы изучения, Москва, с. 8.

Крысин Л. П. (2007), Русская литературная норма и современная речевая практика, [в:] «Русский язык в научном освещении», № 2 (14), Москва, с. 5-17.

Орлов Г. А. (1981), К проблеме грании обиходно-бытовой и современной литературной разговорной речи, [в:] «Вопросы Языкознания», № 5, Москва.

Санджи-Гаряева 3. С. (1984), Просторечные элементы в устной речи жителей г. Элисты, [в:] Городское просторечие. Проблемы изучения, Москва, с. 169.

Резниченко И. Л. (2008), Орфоэпический словарь русского языка, Москва.

http://www.g15.ru/potap_i_nastya_kameskyh_na_raione.html. 
Joanna Woch

\title{
Stylistic accentual variants in the modern Russian language
}

\begin{abstract}
Summary
Russian word stress is an suprasegmental phenomenon, which can distinct stylistic word variants. The word stress distinguishes literary language from slang, professional jargon or other nonstandard Russian language.

Democratisation of the Russian society after 1991 affected the language and its accentual system. Over the past thirty years, there has been a dramatic simplification of the accentual system. The main tendency caused by the intralinguistic rule of analogy is the unification of accent paradigms. However, these rapid changes in spoken language are having a serious effect on Russian literary language which is not prevented from rapid changes by any unified standarisation.

Furthermore, a lack of unified standard and increasing tendency to use wrong accent variants may be a result of extralinguistic factors and far too little attention has been paid to sociolinguistic aspect of language evolution. The study showed that perfect unified standard language and unified pronunciation is unnecessary for an average Russian language speaker. Linguistic correctness, being also a part of a mindset, is just a linguistic category in Russian society, unnecessary to achieve the purpose of communication.

http://bestkino.su/regisser/mixail-zhernevskij/
\end{abstract}

